\title{
Analysis of Factors Affecting Sharia Capital Market Performance in Indonesia
}

Srie Nuning Mulatsih, Aisyah Ratnasari dan Dadang Saepuloh

Universitas Islam Syekh Yusuf Tangerang

E-mail: nuningpurwanto@unis.ac.id, aratnasari@unis.ac.id, dsaepuloh@unis.ac.id

\begin{abstract}
This research is a quantitative descriptive study that aims to measure the performance of the company's Infrastructure, Utilities, and Transportation sectors using Economic Value Added (EVA) and see whether there is value creation for the company after EVA calculation. The population in this study is an infrastructure company listed on ISSI. In contrast, the sample used in this study is 12 infrastructure sector companies listed on the ISSI during 2015-2017, respectively. The type of data used is the type of secondary data that the author gets through the financial statements of each company from 2015-2017 published on the IDX website. The performance measurement method used in this study is the EVA method, which consists of 3 components of calculation, namely Net Operating After-Tax Profit, Weighted Average Cost of Capital, and Invested Capital. The results of this study indicate that the performance of infrastructure sector companies listed on ISSI in the period 2015 to 2017 shows the results of EVA valuations are diverse, namely: Companies that have positive, fixed, negative EVA. PT Cardig Aero Service and TLKM succeeded in showing good EVA growth from 2015-2017. As evidenced by 2017, EVA has continued to increase in 3 consecutive years, having positive EVA values.
\end{abstract}

Keywords. Economic Value Added, Infrastructure, Net Operating After Tax, Weighted Averaged Cost Capital.

\section{INTRODUCTION}

The capital market is an alternative that the company can utilize to meet the capital requirements for the company, where the existing companies conduct stock sale transactions to the public. The companies that have joined the capital market are companies that have to go public. The go public companies are companies that have registered their shares through the capital market. These companies are regulated under the coordination of the Capital Market and Financial Institution Supervisory Agency (Bapepam-LK), which has now become the Financial Services Authority (OJK) (Wahyudiono, 2014).

Therefore, it is suitable for investors first to analyze the information contained in the company's financial statements in considering whether the company's financial performance is good or not. The capital to be invested will be safe and get a favorable return for investors.

The Financial Services Authority has issued a List of Sharia Securities (DES) to facilitate the public in choosing sharia shares. The OJK contains shares included in the Sharia stock category. The following is a growth chart for sharia securities listed on the Indonesia Stock Exchange (BEI) (Sharia Capital Market Roadmap 2015-2019, OJK). 
Graphic 1.1

Development of the number of shares

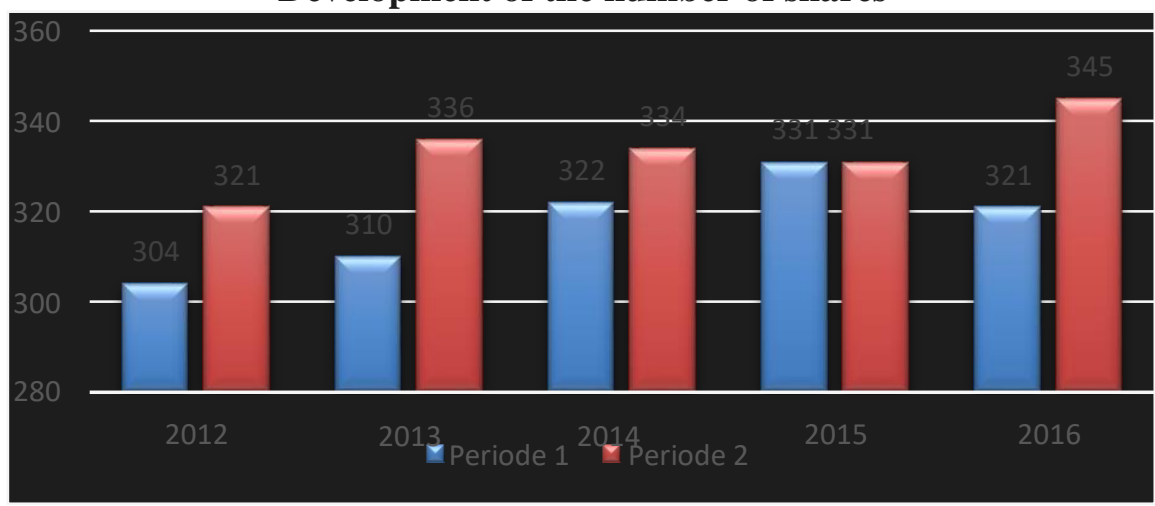

Sources: Compiled from the 2015-2019 PMS Roadmap, the Financial Services Authority (2018).

In graph 1.1 above, it can be seen that the development of the List of Sharia Securities (DES) experienced ups and downs in the number of DES at the turn of the year. With the DES, the public will find it easier to find out what stocks are included in Islamic stocks. DES is the only reference to the list of Islamic stocks in Indonesia. The IDX then followed up the existence of the DES by launching the Indonesian Sharia Stock Index (ISSI) on May 12, 2011. The ISSI constituency consists of all Sharia shares listed on the IDX.

On March 8, 2011, DSN-MUI published Fatwa No. 80 concerning the Application of Sharia Principles in Equity Securities Trading Mechanisms in the Regular Stock Exchange Market. With this fatwa, it should increase public confidence that Islamic investment in the Indonesian capital market follows sharia principles as long as it meets the criteria contained in the fatwa (Financial Services Authority, 2015). So now, Islamic investment in the Indonesian capital market is in the Jakarta Islamic Index (JII) and the Indonesian Islamic Stock Index (ISSI).

It can be seen from table 1.2 To find out the performance of sharia stock trading, the growth of the sharia stock index is below. Based on data from the Indonesia Stock Exchange (IDX), the sharia stock index available until the end of 2016 was the Jakarta Islamic Index (JII) and the Indonesian Sharia Stock Index (ISSI).

Table 1.1

Comparison of Sharia Stock Index with All Stock Index

\begin{tabular}{|c|c|c|c|c|c|c|}
\hline \multicolumn{2}{|c|}{ Stock Index } & $\mathbf{2 0 1 0}$ & $\mathbf{2 0 1 1}$ & $\mathbf{2 0 1 2}$ & $\mathbf{2 0 1 3}$ & $\mathbf{2 0 1 4}$ \\
\hline Sharia & JIM & 532 & 537 & 594 & 585 & 691 \\
\cline { 2 - 7 } Index & ISSI & - & 125 & 144 & 143 & 168,6 \\
\hline Total & LQ 45 & 661 & 673 & 735 & 711 & 898 \\
\cline { 2 - 7 } Index & IHSG & 3.703 & 3.821 & 4.316 & 4.274 & 5.226 \\
\hline
\end{tabular}

Source: Roadmap PMS, Financial Services Authority (2015).

Islamic stocks on the Stock Exchange are classified into each sector. Based on the industrial sector, Islamic stocks are divided into nine industrial sectors. Diagram 1.1 shows that most Islamic stocks come from the trade, service, and investment industry sector, which is as much as $26.41 \%$ of all Islamic stocks. Furthermore, from the Property, Real Estate, and Building Construction sectors as much as $16.2 \%$, Basic and Chemical industry sectors were $13.35 \%$, and other sectors with each share below $10 \%$. 
Picture1.1

Sharia Stock Based On Industrial Sector

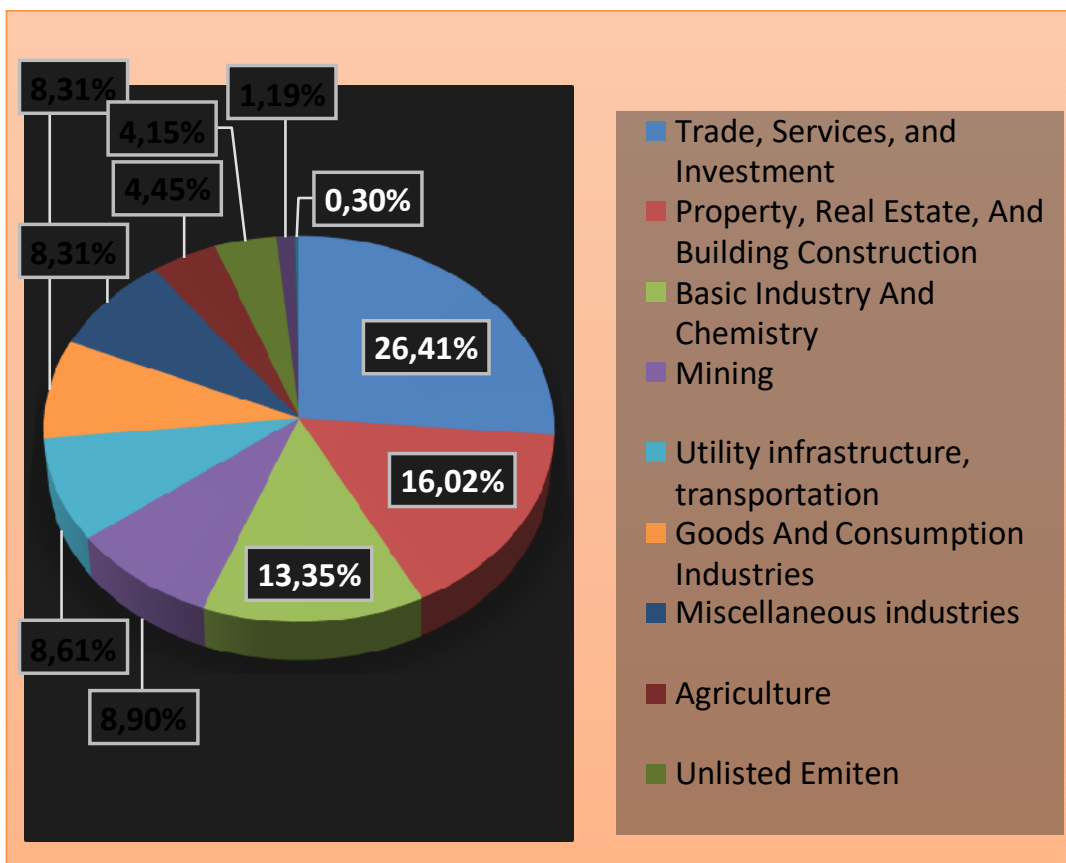

Source: Compiled from Roadmap PMS, OJK (2014).

The list of sharia securities listed on the Stock Exchange has various industrial sectors, wherein there are various sub-sectors in each sector. The Infrastructure sector has a composition of sharia shares amounting to $8.61 \%$ per 2014 , which still has many opportunities to grow more rapidly in the future. The Infrastructure sector is divided into several sub-sectors, including the Energy sub-sector, the Transportation sub-sector, the Telecommunicationssub-sector, the Non-Building Construction subsector, and the Toll Roads Airports, Ports \& the like sub-sector.

\section{Graphic 1.2}

\section{Comparison of industrial sector performance}

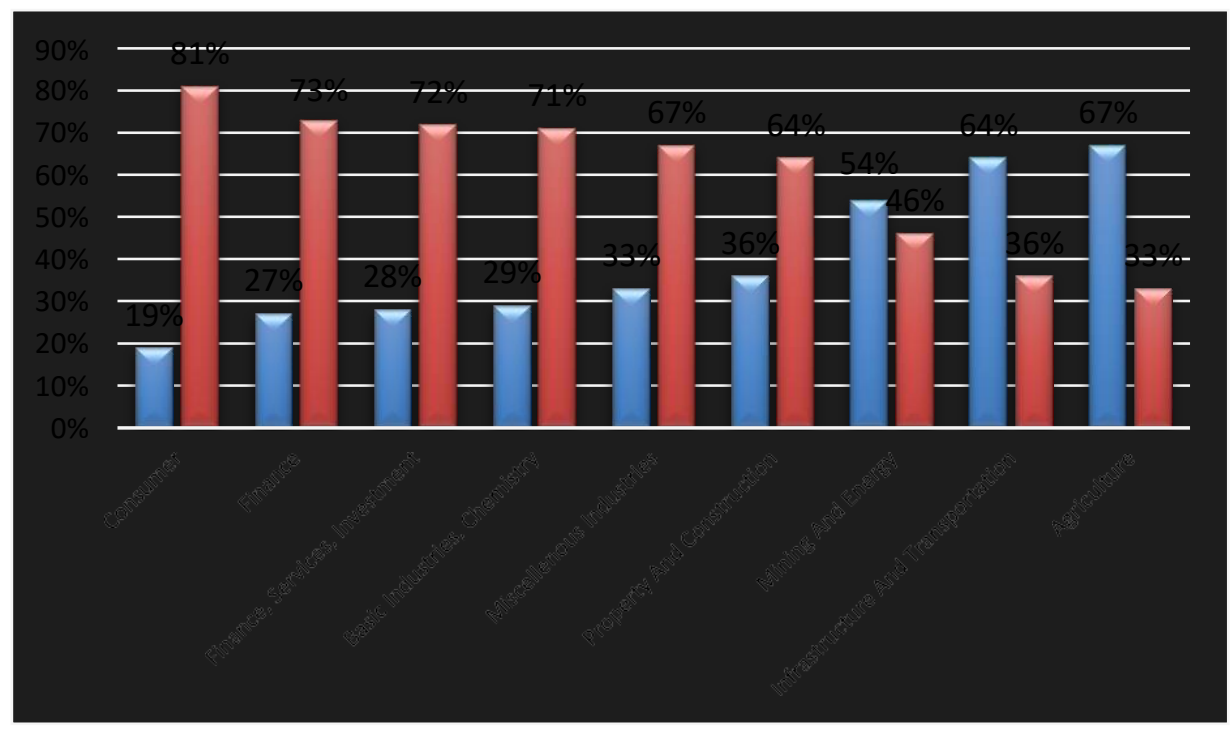

Source: Financial Report, Compiled Bareksa (Ningrum, Dewi (2016) 
Graph 1.2 above shows how the stock performance is seen from the nine industry sectors found on the Indonesia Stock Exchange (IDX). In terms of the industry's overall share in the IDX, in the 2016 financial statements of 151 issuers released to the public, several sectors experienced an increase and decrease in performance.

During the first quarter of 2016, the performance of issuers from the consumer sector experienced an average increase; $81 \%$ of the 16 issuers released to the public had increased. The financial sector and trade, services and industry, and several other sectors also experienced an increase of above $50 \%$. While the decline in performance in the mining and energy sectors experienced a 54\% decline in performance, the infrastructure and transportation sector also experienced a decline of up to 64\%. The agricultural industry sector experienced the highest performance decline compared to other industrial sectors, reaching 67\% (Bareksa. com, 2016).

As shown in graph 1.2 above, there is a decline in performance in 3 industrial sectors, namely the Mining and Energy, Infrastructure and Transportation sectors, and the Agriculture sector. In the Infrastructure industry sector, only $36 \%$ of the 14 issuers that have published their financial reports experienced an increase in financial performance. The company established indeed aims to gain profits or profits for the company and maximize investors' profits. The higher a company experiences an increase in profit, the better the company's performance, especially the company's financial performance.

Table 1.3

Companies Debt Of Infrastructure Sector

\begin{tabular}{|r|r|r|r|}
\hline EMITEN & $\mathbf{2 0 1 4}$ & $\mathbf{2 0 1 5}$ & $\mathbf{2 0 1 6}$ \\
\hline BALI & $440,398,669,631$ & $704,173,745,663$ & $1,005,723,503,533$ \\
\hline CASS & $596,942,115,000$ & $721,089,781,000$ & $852,432,858,000$ \\
\hline CMNP & $1,574,120,576,863$ & $2,015,200,834,726$ & $3,254,522,361,885$ \\
\hline INDX & $5,987,112,356$ & $2,029,082,146$ & $1,368,636,788$ \\
\hline ISAT & $39,058,877,000,000$ & $42,124,676,000,000$ & $36,661,585,000,000$ \\
\hline LAPD & $302,225,778,000$ & $307,200,178,000$ & $263,704,859,000$ \\
\hline LRNA & $85,253,847,669$ & $64,472,906,702$ & $58,358,589,941$ \\
\hline META & $1,709,624,084,553$ & $2,235,704,805,572$ & $2,829,691,155,128$ \\
\hline MIRA & $179,379,148,640$ & $161,377,211,052$ & $153,570,600,374$ \\
\hline
\end{tabular}

Source: Processed Data (2018)

Based on data from table 1.3 shows the amount of debt owed by the four issuers. The data above illustrates that in the 12 companies above experienced an increase in debt each year, more and more dependents must pay the company. Because in addition to paying off debts and running operations, the company must not forget dividends or returns given to investors. The component (profit and debt) is also a component to calculate the company's financial ratios. The results of these financial ratios can briefly illustrate how a company is performing. Furthermore, good company performance will affect the company's stock price. Below is the close price per share for Infrastructure sector companies in the period 2014 to 2016. 
Graphic 1.3

Close Price of Companies Shares of Infrastructure Sector

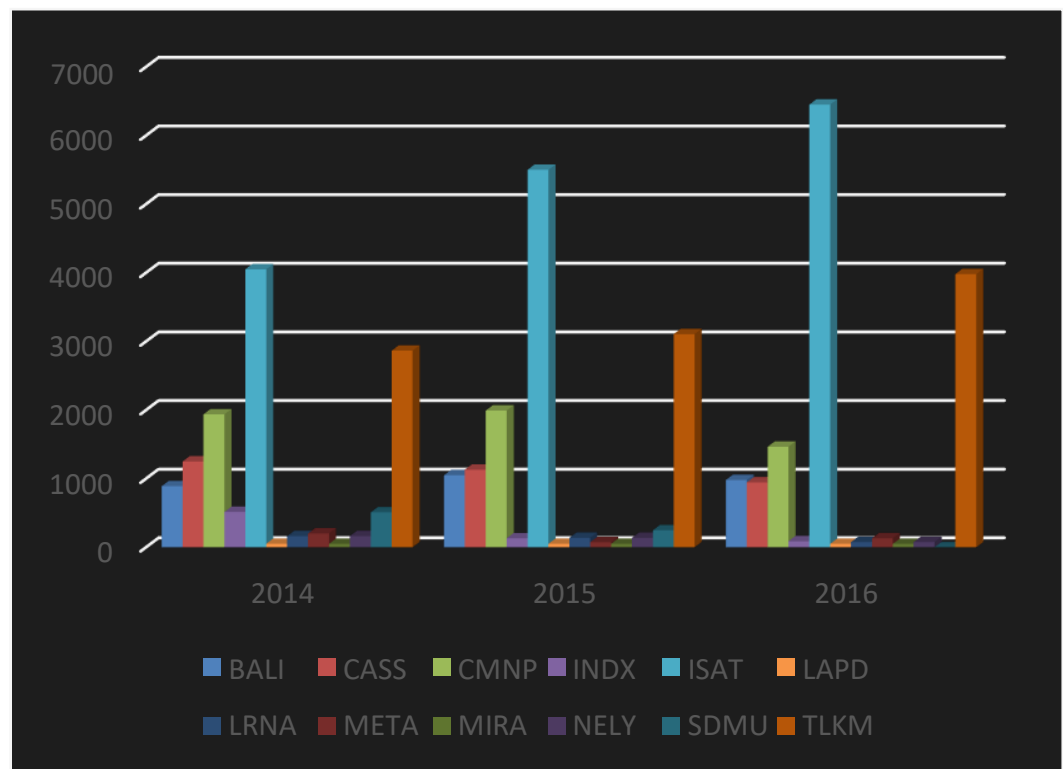

Source: Indonesia Stock Exchange, Processed Data (2018).

Based on graph 1.3 data above is the closing price of shares or the last price obtained for the issuer's shares. The 12 listed companies experienced a rise and fall in stock prices for their companies. In addition to the number of profits, debt, stock prices, the stock returns owned by infrastructure companies also declined. Return is the level of profit or loss that the company will give to all investors for its investment in a certain period.

Table 1.4

Development of Sectoral Stock Returns for the 2011-2015 Period

\begin{tabular}{|c|c|c|c|c|c|c|}
\hline \multirow{2}{*}{ Industri } & & & Tahun & & & \multirow{2}{*}{ Rata-Rata } \\
\hline & 2011 & 2012 & 2013 & 2014 & 2015 & \\
\hline Agriculture & $22,41 \%$ & $-3.87 \%$ & $3,73 \%$ & $9,86 \%$ & $-26.87 \%$ & $1,05 \%$ \\
\hline Mining & $14,93 \%$ & $-26.41 \%$ & $-23.31 \%$ & $-4.22 \%$ & $-40.75 \%$ & $-15.95 \%$ \\
\hline $\begin{array}{l}\text { Basic } \\
\text { Industry }\end{array}$ & $49,04 \%$ & $28,97 \%$ & $-8.70 \%$ & $13,09 \%$ & $-24.98 \%$ & $11,48 \%$ \\
\hline $\begin{array}{l}\text { Miscellaneou } \\
\text { s s Industry }\end{array}$ & $117,99 \%$ & $1,94 \%$ & $-9.84 \%$ & $8,47 \%$ & $-19.11 \%$ & $19,89 \%$ \\
\hline $\begin{array}{l}\text { Consumer } \\
\text { Goods }\end{array}$ & $96,03 \%$ & $18,99 \%$ & $13,81 \%$ & $22,21 \%$ & $-5.19 \%$ & $29,17 \%$ \\
\hline $\begin{array}{l}\text { Property \& } \\
\text { Real Estate }\end{array}$ & $56,17 \%$ & $42,44 \%$ & $3,20 \%$ & $55,76 \%$ & $-6.47 \%$ & $30,22 \%$ \\
\hline Infrastruktur & $-3.99 \%$ & $29,75 \%$ & $2,52 \%$ & $24,71 \%$ & $-15.42 \%$ & $7,51 \%$ \\
\hline Keuangan & $63,15 \%$ & $11,86 \%$ & $-1.77 \%$ & $35,41 \%$ & $-6.10 \%$ & $20,51 \%$ \\
\hline $\begin{array}{l}\text { Trade } \quad \& \\
\text { Service }\end{array}$ & $111,12 \%$ & $27,27 \%$ & $4,84 \%$ & $13,11 \%$ & $-3.31 \%$ & $30,61 \%$ \\
\hline Manufaktur & $87,60 \%$ & $15,66 \%$ & $0,24 \%$ & $16,04 \%$ & $-13.75 \%$ & $21,16 \%$ \\
\hline
\end{tabular}

Source: Processed data by (Ardelia\&Dewi, 2016). 
The data in table 1.4 above shows that some industrial sectors of the stock cannot provide benefits for investors. Even investors must share the costs that are not small. Including the Infrastructure sector, which in 2011 had reached $-3.99 \%$ in 2012 reaching $29.75 \%$, was a pretty good improvement. However, in 2013, the infrastructure sector again recorded a low rate of return for shareholders, which only reached $2.52 \%$. In 2015 also this sector returned could not provide benefits for investors. The investors must share the company's loss to reach $-15.42 \%$. This requires attention and performance evaluation for the company to restore the company's performance to a better level and so as not to disappoint investors. Because when investors are disappointed with the company's performance, the investor may sell the company's shares and be reluctant to invest in the company. So if that happens, it will disrupt the capital circulation for the company.

Every financial statement that is made is sure to have a specific purpose. In practice, there are several objectives to be achieved, especially for business owners and company management. In general, the financial statements provide financial information for a company, both at certain times and in specific periods. Financial statements can provide financial information to internal and external parties interested in the company (Harmono, 2014).

Then the value of company performance becomes a significant measure for shareholders or investors in buying a stock. There have been many studies on financial ratios used to measure company performance. However, now the assessment of company performance is no longer only seen and assessed from the company's financial ratios because financial ratios do not consider the cost of capital generated by the company due to investment. Seeing the limitations in the financial ratio analysis that has been widely used, in 1991, the Stern Stewart \& Co consultancy institute developed a more effective performance analysis system, Economic Value Added, then abbreviated EVA.

EVA presents a good measure of the extent to which the company has provided additional shareholder value. Therefore, if managers focus on EVA, this will help ensure that they consistently maximize stockholders' wealth.

There have been many previous studies discussing EVA on various industrial sector objects and companies included in the IDX, LQ-45, and JII. While research analyzing company value for companies that issue sharia stocks and research in infrastructure sector companies is still small. In connection with this, it is necessary to conduct further research to provide important company information to be known by shareholders or investors to decide to invest in shares following sharia and investing in the right company.

The company established indeed aims to gain profits or profits for the company and maximize investors' profits. The higher a company experiences an increase in profit, the better the company's performance, especially the company's financial performance.

In the 2015-2017 period. There is a downward trend in stock performance; there is a decrease in returns to investors, a downward trend in stock prices, a lack of further research on changes in stock prices in companies that issue Islamic stocks, and the advantages of EVA, so the authors feel the need for research to assess the performance of Infrastructure sector companies. The results of this study can be used to illustrate the answers to existing problems. Therefore, the authors intend to research with the title "ANALYSIS OF FACTORS AFFECTING THE PERFORMANCE OF SHARIA CAPITAL MARKETS IN INDONESIA."

Based on the background described in the previous subchapter, then the formulation of the problem in this study is "What are the factors that influence the Sharia Capital Market in Indonesia, the period 2015-2017?" "How is the performance assessment of the Infrastructure sector companies listed in the Index Indonesian Sharia Stocks (ISSI) use the calculation method of Economic Value Added (EVA)?".

Based on the formulation of the above problem, this study aims to determine the factors that influence the Sharia Capital Market in Indonesia, the 2015-2017 period. Performance evaluation of Infrastructure sector companies listed in the Indonesian Sharia Stock Index (ISSI) using the Economic Value Added calculation method (EVA).

The limitation of the problem in this study is intended as a reference in this study. The limitation of the problem is as follows: 1) The data used is secondary data, in the form of annual reports of each 
infrastructure sector and 2) The documentation in this study is 2015-2017 for the issued of DES and 2015-2017 for the publication of annual reports, which are considered sufficient to be analyzed.

The results of this study are expected to provide benefits to several parties, including 1) For the Islamic capital market, this research can be a contribution to the company to improve the performance of the company further so that it is better than improve anything that makes the company's performance decline; 2) For academics, this research can be insight and science related to performance research for each company. The measurement of the company's financial performance by using the method of Economic Value Added (EVA); 3) For the author, this research is a means of learning in doing scientific works as well as being knowledgeable and knowledgeable about the problems being studied and being a provision for education at the next level and 4) For other researchers, hopefully, this research can be additional information and references that can be used as reference material in increasing your knowledge to develop research.

This study uses the EVA method, which is a way to find out the financial performance of a company whose calculations are obtained through the company's financial report information. By knowing the company's performance, the shareholders can consider future investment decisions in the company.

\section{Illustration of Framework}

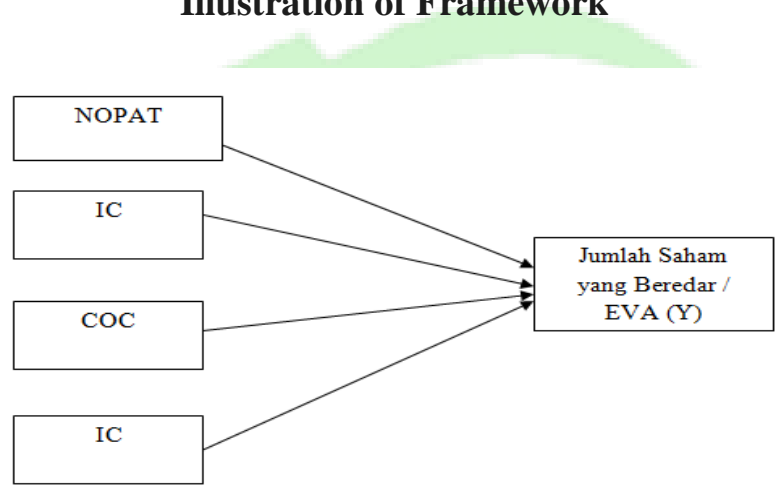

\section{LITERATURE REVIEW THEORETICAL FOUNDATION}

\section{Calculation of EVA}

There are several methods in determining the value of EVA, in this study using the formulation proposed (Young \& O'Byrne, 2001) as follows:

$\begin{array}{ll}\text { EVA } & =\text { NOPAT }- \text { Cost of Capital }(\mathrm{COC}) \\ \text { NOPAT } & =\text { Net Operating Profit After Tax } \\ \text { Cost of Capital } & =\text { WACC } x \text { Invested Capital }\end{array}$

calculate the EVA value of a company, and the following steps are needed:

a. Calculating NOPAT (Net Operating After Tax)

NOPAT or Net Operating After Tax is one of the essential elements in the calculation of EVA. NOPAT itself results from adding between net income and interest costs. Operating income equals sales, less net operating costs, including the cost of goods sold and selling costs, general and administrative costs (Young \& O'Byrne, 2001).

b. Calculating Invested Capital (IC)

IC is the total amount of company finance regardless of short-term liabilities, liabilities that do not bear interest, such as debt, wages that will mature, and taxes that will be due. Invested capital is the number of corporate loans outside of non-interest liabilities.

c. Calculate Weighted Average Cost of Capital (WACC)

WACC is the total cost of each component of capital that is weighted based on its relative proportion in the company's capital structure at market value. The proportion is done because every 
form of financing contains different risks for investors. Therefore, every form of financing chosen by the company contains different costs, consisting of debt and equity.

\section{d. Calculating Cost of Capital (COC)}

The cost of capital is the minimum rate of return expected from investment to meet the return on investment returns desired by investors. This capital cost includes clear elements, such as interest payments to bankers and bondholders and the opportunity costs of capital invested by the company's shareholders. This can also be interpreted as the minimum value of NOPAT needed to produce a positive EVA.

\section{PREVIOUS RESEARCH}

The research conducted by Juliana et al. (2018) entitled The Growth and Equity of Economic in the Perspective of Politics in Islamic Economic show that there was still unbalance of income equity that affected citizens to receive shared prosperity. The findings from the research show the economic growth according to Islamic Economy is related to the material development of life standards. Besides, the ideal economic growth will be able to be created optimally and affect the equity of the economy if it uses the politic of the Islamic economy through direct and indirect strategies. The research by ALMIZAN (2016) entitled Economy Development in the Perspective of Islamic Economy describes economic development as one of the strategies to achieve the desired goal of the nation. The goal includes how poverty, unemployment, economy, and social disparity are solved to realize humanity's prosperity.

Further, economic development is described as the development of human maturity where material development could not be avoided and supported by spiritual maturity. The most crucial purpose of employment growth added by trustworthy skills will become work with high quality, economic stability, fair distribution, and environment friendly. Islamic comprehensive economy development has the characteristic of spiritual, moral, material, and the activity tends to be multidimensional. Thus, businesses can balance the factors and eliminate inequality.

\section{RESEARCH METHODOLOGY}

The calculation of the company's performance using the EVA method will later be presented in the form of numbers. This research will describe or illustrate the analysis results carried out in measuring the performance appraisal for the Infrastructure industry sector companies listed in ISSI by using the Economic Value Added (EVA) method. The data that is material in this study is sourced from secondary data. According to (Misbahuddin\& Hasan, 2014), secondary data is data obtained or collected by people who research existing sources. This data is usually obtained from libraries or previous research reports.

The population used in this study were all infrastructure sector companies registered for five years from 2012-2016 and companies that used Rupiah units in their financial statements. The population in this study also includes the five existing sub-sectors in the infrastructure sector, namely the energy, transportation, telecommunications, toll roads \& airports sector, and non-construction buildings that issue sharia shares and are listed in the Indonesian Sharia Stock Index (ISSI) for some time. It has been determined that it is 2012- 2016. The population in this study was 12 infrastructure sector companies listed on ISSI.

Sampling was carried out based on the purposive sampling method, namely sampling with specific criteria. The sample criteria in this study are as follows: 1) Included in the infrastructure sector companies listed on the 2012-2016 Indonesia Sharia Stock Index; 2) Infrastructure sector companies engaged in transportation; 3) The company issues financial statements for the period 2012-2016. Based on the criteria that have been established using the purposive sampling method, there are six infrastructure sector companies listed on the Indonesian Sharia Stock Index (ISSI) during 2015-2017, which were sampled. Following are the names of the companies that are the samples of this study: 
Table 2. List of Sampling Manufacturing Companies

\begin{tabular}{|c|l|l|}
\hline No & \multicolumn{1}{|c|}{ Stock Code } & Emiten \\
\hline 1 & CASS & Cardig Aero Service Tbk \\
\hline 2 & INDX & Tanah LautTbk \\
\hline 3 & LRNA & Sari Lorena Transport Tbk \\
\hline 4 & MIRA & $\begin{array}{l}\text { MitraInternasional } \\
\text { Resources Tbk }\end{array}$ \\
\hline 5 & NELY & $\begin{array}{l}\text { Pelayaran Nelly } \\
\text { DwiPutriTbk }\end{array}$ \\
\hline 6 & SDMU & SidomulyoSelarasTbk \\
\hline 7 & TLKM & Telkom,Tbk \\
\hline 8. & BALI & Bali Towerindo Sentra,Tbk \\
\hline 9. & CMNP & $\begin{array}{l}\text { Citra Marga Nushapala } \\
\text { Persada,Tbk }\end{array}$ \\
\hline 10. & ISAT & Indosat,Tbk \\
\hline 11. & META & Nusantara Infrastructur,Tbk \\
\hline 12. & LAPD & Lapindo International,Tbk \\
\hline
\end{tabular}

Source: www.Saham ok.co.id \& www.IDX.co.id

\section{DISCUSSION}

1. The Calculation of Economic Value Added

Table 4.1. NOPAT Calculation of Infrastructure Sector Companies

\begin{tabular}{|l|l|l|l|}
\hline \multicolumn{5}{|c|}{ Net Operating After Tax (NOPAT) } \\
\hline Emiten & 2015 & 2016 & 2017 \\
\hline BALI & $-1,215,148,818$ & $275,133,021,712$ & $174,597,994,133$ \\
\hline CASS & $334,845,503$ & $339,782,404$ & $378,978,702$ \\
\hline CMNP & $536,273,851,043$ & $613,248,462,060$ & $792,600,059,369$ \\
\hline INDX & $2,360,202,853$ & $17,777,892,526$ & $58,014,687,710$ \\
\hline ISAT & $1,040,402,000$ & $3,113,941,000$ & $1,304,050,246$ \\
\hline LAPD & $-64,302,293,000$ & $-45,300,040,000$ & $-101,042,866,000$ \\
\hline LRNA & $3,860,432,944$ & $-32,099,174,146$ & $-42,096,446,259$ \\
\hline META & $451,031,020,370$ & $431,020,813,619$ & $3,226,115,243,054$ \\
\hline MIRA & $-1,215,148,818$ & $-27,589,929,498$ & $21,774,177,411$ \\
\hline NELY & $33,203,692,650$ & $17,487,864,197$ & $22,462,229,367$ \\
\hline SDMU & $24,576,602,224$ & $16,532,726,565$ & $55,584,539,307$ \\
\hline TLKM & $23,557,000,000,000$ & $29,383,000,000,000$ & $35,834,000,000,000$ \\
\hline
\end{tabular}

Source: Processed Data 2018

Based on the results of the NOPAT calculation in the 12 companies above, it is known that the NOPAT value of the 12 companies experienced fluctuations from 2015 to 2017. Some companies experienced a decline in 2015 and can be seen by the financial statements of PT MITRA INTERNATIONAL with the MIRA stock code. MIRA experienced a decrease in NOPAT value in 2015 reaching - 1,215,148,818 and decreased drastically in $2016-27,589,929,498$. The same thing happened to companies with the stock code NELY, SDMU, TLKM. Due to the decline in profits and even losses experienced by the three companies in 2015-2017.

PT. NELLY DWI PUTRI DELIVERY with NELLY stock code also has a NOPAT value fluctuating in 2015-2017. In 2015 the results of 33,203,692,650 and declined again in 2016 were $17,487,864,197$ and experienced a rebound in 2017 with 22,462,229,367 results. So it must be borne by each company. 


\section{The Calculation of Invested Capital (IC)}

Table 4.2. Invested Capital (IC) Calculation

\begin{tabular}{|l|l|l|l|}
\hline \multicolumn{5}{|c|}{ Invested Capital (IC) } \\
\hline Emiten & 2015 & 2016 & 2017 \\
\hline BALI & $409,979,790,026$ & $335,751,347,623$ & $1,926,354,431,979$ \\
\hline CASS & $862,101,009$ & $1,292,919,190$ & $1,280,713,780$ \\
\hline CMNP & $3,193,849,111,456$ & $3,468,584,097,303$ & $90,886,321,610,427$ \\
\hline INDX & $179,795,917,527$ & $161,850,361,253$ & $109,578,240,260$ \\
\hline ISAT & $35,335,917,000$, & $31,752,112,000$ & $34,460,583,000$ \\
\hline LAPD & $557,165,790,000$ & $686,495,799,000$ & $410,163,861,000$ \\
\hline LRNA & $294,632,630,991$ & $267,255,123,020$ & $228,894,057,858$ \\
\hline META & $4,283,364,076,521$ & $5,068,334,703,664$ & $4,858,410,674,526$ \\
\hline MIRA & $409,979,790,026$ & $335,751,347,623$ & $311,168,106,926$ \\
\hline NELY & $393,013,354,716$ & $386,622,048,205$ & $381,645,902,983$ \\
\hline SDMU & $285,284,085,241$ & $338,540,001,360$ & $295,407,054,650$ \\
\hline TLKM & $130,760,000,000$ & $-39,582,389,000,000$ & $-45,177,516,000,000$ \\
\hline
\end{tabular}

Source: Processed Data 2018

Value of Invested Capital (IC) in 12 companies, Citra MargaNusaphalaPersadaTbk with CMNP stock code has increased IC value for three consecutive years, while five companies experienced decreased IC value in that period. Five companies experienced impairment, namely INDX, LRNA, MIRA, NELY, TLKM. Whereas for PT Cardig Aero Services with the CASS stock code, it was able to increase the company's IC value in the three periods above, even though the company had experienced a decline in profits and also an increase in interest expense in 2015 and a decline in the company's NOPAT value in 2016.

\section{WACC Calculation Result}

Table 4.3. The Calculation Weight Average Cost of Capital (WACC)

\begin{tabular}{|l|l|l|l|}
\hline \multicolumn{3}{|c|}{ WATCH } \\
\hline Emiten & 2015 & 2016 & 2017 \\
\hline BALI & $26,36 \%$ & $19,75 \%$ & $45,31 \%$ \\
\hline CASS & $-7,33 \%$ & $14,58 \%$ & $6,28 \%$ \\
\hline CMNP & $58,07 \%$ & $49,35 \%$ & $978,50 \%$ \\
\hline INDX & $20,54 \%$ & $154,81 \%$ & $10,37 \%$ \\
\hline ISAT & $11,53 \%$ & $37,29 \%$ & $11,13 \%$ \\
\hline LAPD & $74,68 \%$ & $31,78 \%$ & $22,20 \%$ \\
\hline LRNA & $-87,99 \%$ & $-44,05 \%$ & $97,02 \%$ \\
\hline META & $50,20 \%$ & $35,91 \%$ & $37,29 \%$ \\
\hline MIRA & $-45,91 \%$ & $-10,70 \%$ & $10,23 \%$ \\
\hline NELY & $0,50 \%$ & $2,69 \%$ & $1,67 \%$ \\
\hline SDMU & $20,10 \%$ & $25,90 \%$ & $17,18 \%$ \\
\hline TLKM & $2,90 \%$ & $3,00 \%$ & $18,80 \%$ \\
\hline SOurCe: Processed & & \\
\hline
\end{tabular}

Source: Processed Data 2018

In 2015 almost all infrastructure sector companies experienced a decrease in the WACC value; this was due to increased debt costs and corporate equity costs. Regarding the development of values from the WACC, many companies experienced a decline and also increased. It can be seen that LRNA of $-87.99 \%$ in 2015 owns the lowest WACC value. Whereas for companies with the highest WACC value is owned by the LAPD stock code worth $74.68 \%$ in 2015 but decreases in 2016 and 2017. Then followed by MIRA, which has a WACC value of $-45.91 \%$ in 2015, then increased in 2016 AND 2017. 


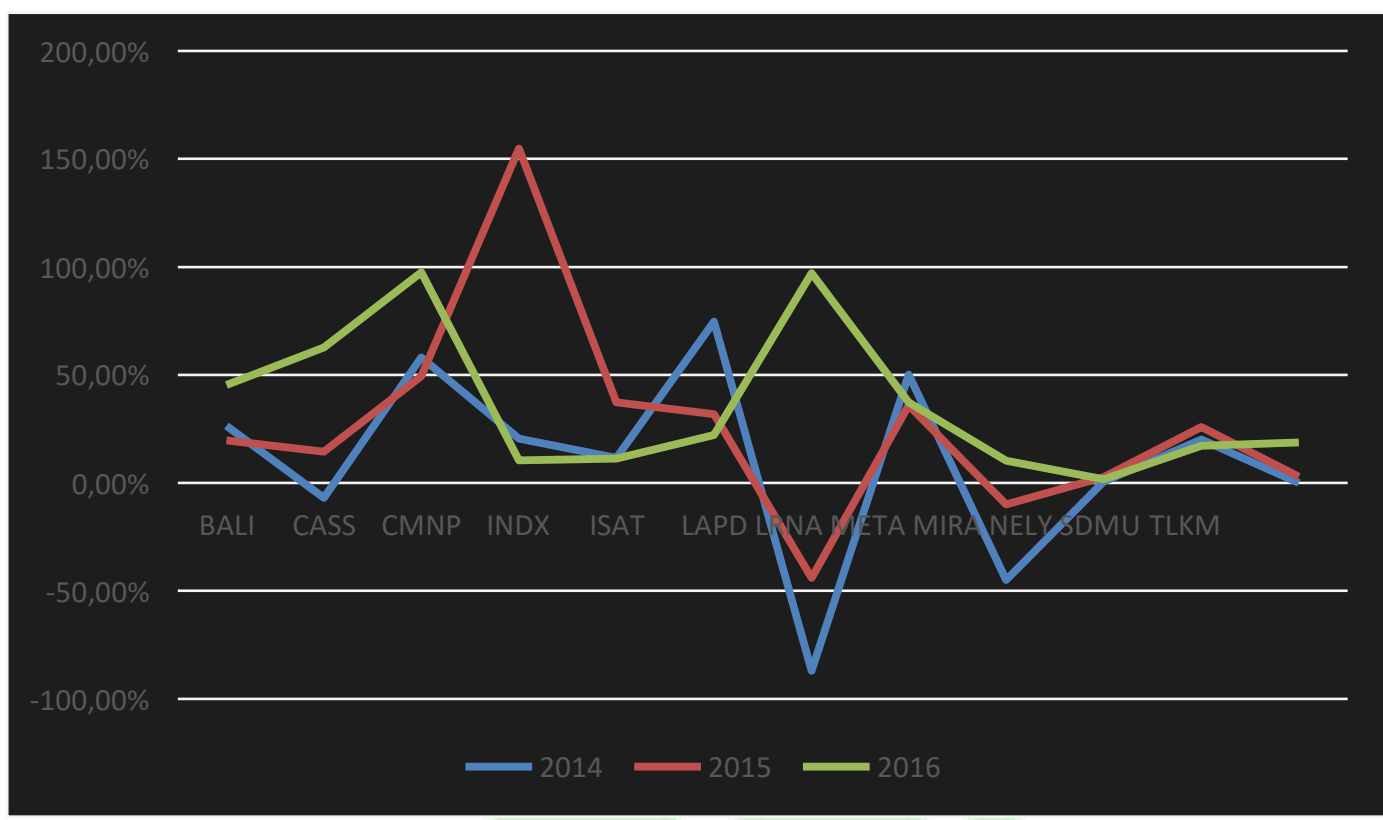

Graph 4.1. WACC Calculation Result

\section{Cost of Capital Calculation Result}

Table 4.4 Cost of Capital Calculation

\begin{tabular}{|l|l|l|l|}
\hline \multicolumn{5}{|c|}{ Cost Of Capital(COC) } \\
\hline Emiten & 2015 & 2016 & 2017 \\
\hline BALI & $-188,221,721,601$ & $-35,925,394,196$ & $872,831,193,130$ \\
\hline CASS & $-63,192,004$ & $188,507,618$ & $80,428,825$ \\
\hline CMNP & $3,193,849,111,456$ & $3,468,584,097,303$ & $90,886,321,610,427$ \\
\hline INDX & $36,930,081,460$ & $250,560,544,256$ & $11,363,263,515$ \\
\hline ISAT & $4,074,231,230$ & $11,840,362,565$ & $3,835,462,888$ \\
\hline LAPD & $26,388,862,816$ & $10,090,821,194$ & $-91,056,377,142$ \\
\hline LRNA & $-259,247,252,008$ & $-117,725,881,690$ & $222,073,014,935$ \\
\hline META & $2,150,248,766,414$ & $1,820,038,992,086$ & $1,811,761,340,531$ \\
\hline MIRA & $-188,221,721,601$ & $-35,925,394,196$ & $31,832,497,339$ \\
\hline NELY & $1,965,066,774$ & $10,400,133,097$ & $6,373,486,580$ \\
\hline SDMU & $57,342,101,133$ & $87,681,860,352$ & $50,750,931,989$ \\
\hline TLKM & $3,792,040,000,000$ & $-1,187,471,670,000$ & $-8,493,373,008,000$ \\
\hline SOurC: Proc & & & \\
\hline
\end{tabular}

Source: Processed Data 2018

In the calculation of the Cost of Capital, it can be seen that the COC value has increased and also decreased in the 2015-2017 period. However, in 2016 the average infrastructure sector company experienced an increase in COC. Three companies have increased in the last three years, namely BALI, CMNP LRNA. CMNP includes one of them from infrastructure sector companies with a cost of capital increase of $25 \%$ in 2017 compared to 2016, which only increased 8. The greater the cost of capital, this illustrates the minimum return achieved. This is related to the enormous WACC value in the same year, meaning that the company can maintain liquidity. 


\section{Economic Value Added Calculation Result}

Table 4.5. Economic Value Added (EVA) Calculation Result

\begin{tabular}{|l|l|l|l|}
\hline \multicolumn{5}{|c|}{ Economic Value Added(EVA) } \\
\hline Emiten & 2015 & 2016 & 2017 \\
\hline BALI & $187,006,572,783$ & $8,335,464,698$ & $-698,233,198,997$ \\
\hline CASS & $398,137,507$ & $151,274,786$ & $298,549,877$ \\
\hline CMNP & $-2,657,575,260,413$ & $-2,855,335,635,243$ & $-90,093,721,551,058$ \\
\hline INDX & $-34,569,878,607$ & $-232,782,651,730$ & $46,651,424,195$ \\
\hline ISAT & $-3,033,829,230$ & $-8,726,421,565$ & $-2,531,412,641$ \\
\hline LAPD & $-90,691,155,816$ & $-55,390,861,194$ & $-9,986,488,858$ \\
\hline LRNA & $263,107,684,952$ & $85,626,705,544$ & $-264,169,461,194$ \\
\hline META & $-1,699,217,746,044$ & $-1,389,018,178,467$ & $1,344,413,902,523$ \\
\hline MIRA & $187,006,572,783$ & $8,335,464,698$ & $-10,058,319,928$ \\
\hline NELY & $31,238,625,906$ & $7,087,731,100$ & $16,088,742,787$ \\
\hline SDMU & $-32,765,498,909$ & $-71,149,133,787$ & $4,833,507,318$ \\
\hline TLKM & $19,764,960,000,000$ & $30,570,471,670$ & $44,327,373,108,000$ \\
\hline SLI
\end{tabular}

Source: Processed Data 2018

The results of EVA calculations in table 4.5 show that most infrastructure sector companies that are sampled show fluctuating EVA values. TLKM succeeded in showing good EVA growth from 20152017, as evidenced by 2017 EVA owned continued to rise in 3 consecutive years. In contrast, BALI and LRNA experienced a decline in 2017, which was very drastic from the previous year to reach a minus number compared to the previous year, which had a positive EVA value. Indosat also has a poor EVA value in 2015 and 2016; lucky Indosat can immediately restore the condition of the company in terms of EVA value in 2016. However, the EVA value still has a negative value. In contrast, PT Cardig Aero Service has had a positive EVA value for three consecutive years.

\section{CLOSING}

\section{Conclusion}

Based on the results of EVA calculations shows that the majority of infrastructure sector companies that are sampled show various EVA values where:

a. PT Cardig Aero Service and TLKM succeeded in showing good EVA growth from 2015-2017; as evidenced by 2017, EVA has continued to increase in 3 consecutive years, having positive EVA values.

b. Indosat has fewer EVA values in 2015 and 2016, Indosat can immediately restore the company's condition in terms of EVA value in 2016, but the EVA value still has a negative value.

c. BALI and LRNA experienced a drastic decline in 2017 from the previous year to reach a minus number compared to the previous year, which had a positive EVA's value.

\section{Suggestion}

1. For Infrastructure Sector Companies, because many factors affect the value of EVA, it can use the following strategies in order to maintain or even increase the value of EVA in the next period, including:

a. It can be more efficient in the capital spent by the company to get capital for the company.

b. Can maintain the company's profit/profit value.

c. Always provide clear and detailed information to all investors regarding the condition of

d. the company.

2. For Investors, to be more careful if we want to invest in a company, it would be nice first to measure the company's performance.

3. For Researchers Next, to increase the period of the period so that the company's performance can be more comprehensive. 


\section{REFERENCE}

Abdullah, B., \& Saebani, B. A. (2014). Metode Penelitian Ekonomi Islam (Muamalah). Bandung: CV Pustaka Setia.

Akbar, A., Hernawan, A., \& Beik, S. I. (2014). Analisis Stabilitas Kinerja Saham Syariah Pada ISSI. Ekonomi Islam Republika.

Antonio, M. S. (2001). Bank Syariah; Dari Teori ke Praktik. Jakarta: Gema Insani Press.

Ardelia, I., \& Dewi, F. R. (2016, Desember). Analisis Kinerja Portofolio Saham Sektor Pertambangan dan Saham Sektor Perdagangan. Jurnal Manajemen dan Organisasi, VII, No 3.

Arikunto, S. (2002). Prosedur Penelitian. Jakarta: PT. Rineka Cipta.

Bareksa.com. (2016, Mei 9).

Bass, B. M. (1985). Leadership and Performance Beyond Expectation. New York: Free Press.

Bossert, S. T., Dwyer, D. C., Rowan, B., \& Lee, G. V. (1982). The Instructional Management Role of the Principal. Educational Administration Quarterly, 77-96.

Fahmi, I. (2014). Analisis Laporan Keuangan. Bandung: Allfabeta.

Ginanjar, G., \& Ferlina, A. (2015, Agustus). Analisis Kinerja Keuangan Dengan Menggunakan Metode EVA dan MVA. e-Proceding of Management, Vol.2, No.2, 1886-1892.

Harmono. (2014). Manajemen Keuangan Berbasis Balanced Scorecard (Vols. Edisi satu, Cetakan 3). (R. Rachmatika, Ed.) Jakarta: PT Bumi Aksara.

Irawan, P. (2006). Penelitian Kualitatif dan Kuantitatif untuk Ilmu-Ilmu Sosial. Jakarta: DIA FISIP UI.

amaludin, \& Indriani, R. (2012). Manajemen Keuangan "Konsep Dasar dan Penerapannya". Bandung: CV. Mandar Maju.

Listiadi, A. (2015). Pengaruh Kinerja Keuangan Terhadap Nilai Perusahaan Sebagai Manifestasi Pembelajaran Investasi. Jurnal Ekonomi Pendidikan dan Kewirausahaan, Vol. 3, No. 1, 17.

Margaretha, F. (2007). Manajemen Keuangan. Jakarta: Gramedia Widiasarana Indonesia.

Misbahuddin, \& Hasan, I. (2014). Analisis Data Penelitian Dengan Statistik. Jakarta: Bumi Aksara.

Nugraha, F., \& Bahtiar, M. D. (2013). Pengaruh Return on Equity dan Economic Value Added Terhadap Nilai Perusahaan. Jurnal Akuntansi dan Keuangan Islam, Vol.1, No.1.

Rallya, F. M. (2017). Analisis Kinerja Dengan Metode Economic Value Added (EVA) Pada Perusahaan Sektor Industri Pertambangan Yang Terdftar Di ISSI. 16.

Sudana, I. M. (2011). Manajemen Keuangan Perusahaan Teori dan Praktik. Penerbit Erlangga.

Sulistyaningsih, V. (2017). Analisis Kinerja Keuangan Dengan Metode Economic Value Added (EVA) Pada Perusahaan Telekomunikasi Yang Terdaftar Di Bursa Efek Indonesia. Pendidikan dan Ekonomi, 10.

Sunardi, H. (2010, Mei). Pengaruh Penilaian Kinerja dengan ROI dan EVA terhadap Return Saham pada Perusahaan yang Tergabung dalam Indeks LQ 45 di Bursa Efek Indonesia. Jurnal Akuntansi, Vol.2, No.1, 23. 
Abdullah, B., \& Saebani, B. A. (2014). Metode Penelitian Ekonomi Islam (Muamalah). Bandung: CV Pustaka Setia.

Akbar, A., Hernawan, A., \& Beik, S. I. (2014). Analisis Stabilitas Kinerja Saham Syariah Pada ISSI. Ekonomi Islam Republika.

Antonio, M. S. (2001). Bank Syariah; Dari Teori ke Praktik. Jakarta: Gema Insani Press.

Ardelia, I., \& Dewi, F. R. (2016, Desember). Analisis Kinerja Portofolio Saham Sektor Pertambangan dan Saham Sektor Perdagangan. Jurnal Manajemen dan Organisasi, VII, No 3.

Arikunto, S. (2002). Prosedur Penelitian. Jakarta: PT. Rineka Cipta.

Bareksa.com. (2016, Mei 9).

Bass, B. M. (1985). Leadership and Performance Beyond Expectation. New York: Free Press.

Bossert, S. T., Dwyer, D. C., Rowan, B., \& Lee, G. V. (1982). The Instructional Management Role of the Principal. Educational Administration Quarterly, 77-96.

Danim, S. (2003). Menjadi Komunitas Pembelajar, Kepemimpinan Transformasional dalam Komunitas Organisasi Pembelajaran. Jakarta, Indonesia: PT. Bumi Aksara.

Danim, S. (2005). Pembelajaran Berbasis Kompetensi. Jakarta: Raja Grafindo.

Djaali, P. M. (2000). Pengukuran dalam Bidang Pendidikan. Jakarta: Program Pascasarjana Universitas Negeri Jakarta.

Fahmi, I. (2014). Analisis Laporan Keuangan. Bandung: Allfabeta.

Fathurrahim, F. (2009, Juni 25). Bagaimana Hukum Nikah Mut'ah. Dipetik Juni 20, 2011, dari Sejarahku Sejarahmu (Blogspot): http://sejarahkusejarahmu.blogspot.com/2009/06/bagaimana-hukum-

nikah-mut'ah/

Fattah, N. (2000). Landasan Manajemen Pendidikan. Bandung: PT. Remaja Rosdakarya. Fauklner, A. (2008, Agustus 13). Wanita-wanita Yang Haram Dinikahi. Dipetik Juni 23, 2011, dari Dunia Pernikahan (Wordpress): http://duniapernikahan.wordpress.com/2008/08/13/wanita-wanitayang-haram-dinikahi/

Ginanjar, G., \& Ferlina, A. (2015). Analisis Kinerja Keuangan Dengan Menggunakan Metode Economic Value Added (EVA) dan Market Value Added (MVA). 1-8.

Ginanjar, G., \& Ferlina, A. (2015, Agustus). Analisis Kinerja Keuangan Dengan Menggunakan Metode EVA dan MVA. e-Proceding of Management, Vol.2, No.2, 1886-1892.

Hallinger, P., \& Murphy, J. (1986). Assessing the Instructional Management Behavior of Principals. The Elementary School Journal, 86(2), 217-247.

Harmono. (2014). Manajemen Keuangan Berbasis Balanced Scorecard (Vols. Edisi satu, Cetakan 3). (R. Rachmatika, Ed.) Jakarta: PT Bumi Aksara.

Irawan, P. (2006). Penelitian Kualitatif dan Kuantitatif untuk Ilmu-Ilmu Sosial. Jakarta: DIA FISIP UI.

Kamal, A. M. (2007). Fiqih Sunnah Wanita (1st ed.). (M. Ghozi, Penerj.) Jakarta, Jakarta, Indonesia: Pena Pundi Aksara. 
Kamaludin, \& Indriani, R. (2012). Manajemen Keuangan "Konsep Dasar dan Penerapannya". Bandung: CV. Mandar Maju.

Listiadi, A. (2015). Pengaruh Kinerja Keuangan Terhadap Nilai Perusahaan Sebagai Manifestasi Pembelajaran Investasi. Jurnal Ekonomi Pendidikan dan Kewirausahaan, Vol. 3, No. 1, 17.

Lysim, M. (2010, Desember 04). Nikah Mut'ah Versi Sunni dan Nikah Mut'ah Versi Syiah. Dipetik Juni 23, 2011, dari MintLysim (Wordpress): http://mintlysim.wordpress.com/2010/12/04/nikahmut'ah-versi-sunni-dan-nikah-mut'ah-versi-syiah/

Margaretha, F. (2007). Manajemen Keuangan. Jakarta: Gramedia Widiasarana Indonesia.

Misbahuddin, \& Hasan, I. (2014). Analisis Data Penelitian Dengan Statistik. Jakarta: Bumi Aksara.

Musthafa, I. (1999). Perkawinan Mut'ah dalam perspektif Hadist dan tinjauan masa kini. Jakarta, Indonesia: Lentera Bashritama.

Nugraha, F., \& Bahtiar, M. D. (2013). Pengaruh Return on Equity dan Economic Value Added Terhadap Nilai Perusahaan. Jurnal Akuntansi dan Keuangan Islam, Vol.1, No.1.

Rallya, F. M. (2017). Analisis Kinerja Dengan Metode Economic Value Added (EVA) Pada Perusahaan Sektor Industri Pertambangan Yang Terdftar Di ISSI. 16.

Ramulyo, M. I. (2000). Hukum Perkawinan, Hukum kewarisan, Hukum acara Peradilan agama, dan Zakat Menurut Hukum Islam. Jakarta: Sinar Grafika.

Sabiq, S. (2006). Fiqh Sunnah (1st ed.). (P. N. Raya, Penyunt.) Jakarta, Jakarta, Indonesia: PT Pena Pundi Aksara.

Sahla, A., \& Nazara, N. (2011). Buku Pintar Pernikahan (1st ed.). Jakarta, Jakarta, Indonesia: Belanoor.

Sevilla, C. G. (1993). Pengantar Metode Penelitian. (A. Syah, Penerj.) Jakarta: UI Press.

Shagharji, A. A. (2008). Fiqh Hanafi wa Adillatuhu. Damascus, Syria: Darul Kilmi At-thoyyib.

Sudana, I. M. (2011). Manajemen Keuangan Perusahaan Teori dan Praktik. Penerbit Erlangga.

Sugiyono. (2016). Metode Penelitian Pendidikan (Vols. Cetakan Ke-23). Bandung: Alfabeta.

Sujarweni, V. W. (2014). Metodolgi Penelitian. Yogyakarta: PUSTAKABARUPRESS.

Sulistyaningsih, V. (2017). Analisis Kinerja Keuangan Dengan Metode Economic Value Added (EVA) Pada Perusahaan Telekomunikasi Yang Terdaftar Di Bursa Efek Indonesia. Pendidikan dan Ekonomi, 10.

Sunardi, H. (2010, Mei). Pengaruh Penilaian Kinerja dengan ROI dan EVA terhadap Return Saham pada Perusahaan yang Tergabung dalam Indeks LQ 45 di Bursa Efek Indonesia. Jurnal Akuntansi, Vol.2, No.1, 23.

Sururuddin. (2009, Maret 23). Beberapa Pandangan Tentang Nikah Mut'ah. Dipetik Juni 17, 2011, dari Sururuddin (Wordpress): http://sururdin.wordpress.com/2009/03/23/beberapa-pandangantentang-nikah-mut'ah/

Susanti, S. (2002). Pengaruh Manajerial Kepala Sekolah terhadap Efektivitas Organisasi. Kediri: Universitas Islam Kediri.

Suwanta, T. (2010). Pedoman Penulisan Karya Tulis Ilmiah. (I. Jaya, A. Supriatna, \& I. Wahyudi, Penyunt.) Tangerang, Banten, Indonesia: Daar el-Qolam Press. 
Syurbashi, A. (2006). Biografi Empat Imam Madzhab (2nd ed.). (E. Rachmawati, Penyunt., \& A. M. Alimin, Penerj.) Solo, Jawa tengah, Indonesia: Media Insani Press.

Utomo, L. L. (1999). Economic Value Added Sebagai Ukuran Keberhasilan Kinerja Manajemen Perusahaan. Jurnal Akuntansi dan Keuangan, 1-15.

Wahyudiono, B. (2014). Mudah Membaca Laporan Keuangan. Jakarta: Raih Asa Sukses.

Wibowo. (2016). Manajemen Kinerja. Jakarta: Rajawali Pers.

Winarno, S. H. (2014, Oktober). Analisis Kinerja Keuangan Menggunaka Metode Penerapan Value Adeed. Moneter, 1, 10.

Winarno, S. H. (2014). Analisis Penilaian Kinerja Keuangan Menggunakan Penerapan Economic Value Added. Moneter, 1-10.

Yafiz, M. (2008, Juli-Desember 2). Saham dan Pasar Modal Syariah. MIQOT, Vol. XXXII, No. 2.

Young, S. D., \& O'Byrne, S. F. (2001). EVA and Value-Based Management: A Practical Guide to Implementation. (L. Widjaja, Trans.)

Zahara, M., \& Haryanti, D. A. (2011, Oktobel). Pengukuran Kinerja Keuangan Dengan Menggunakan Metode E 